\title{
WORD ORDER IN SIMPLE NARRATIVE SENTENCES IN THE OLD SPANISH LANGUAGE (BY THE EXAMPLE OF FORMAL LETTERS)
}

\author{
Svetlana Bezus ${ }^{1}$ and Irina Kobyakova ${ }^{2 \star}$ \\ ${ }^{1}$ Ph.D. in Pedagogy, Associate Professor, North-Caucasus Federal University, Pyatigorsk branch, \\ Department of Linguistics and Intercultural Communication, RUSSIA, luzazul@list.ru \\ ${ }^{2}$ Ph.D. in Pedagogy, Associate Professor, Piatigorsk State Linguistic University, Department of \\ Hispanic Studies and Intercultural Communication, RUSSIA, kobyakova@pgu.ru \\ ${ }^{*}$ Corresponding author
}

\begin{abstract}
There are different classifications of sentences. Structurally-typological approach to the classification of sentences is based on a comparison of the word order, i.e. the position of main and secondary components in a simple sentence. Such an approach follows from the theory of language typology elaborated by the American linguist J. Greenberg. In the theoretical part the report provides the main thesis of the classical Greenberg's theory, which is based on the order of the basic components of a simple sentence: subject (S), verb $(\mathrm{V})$ and object $(\mathrm{O})$. According to this theory any language admits different configurations of the elements: SVO, SOV, VSO, VOS, OSV or OVS, but the dominant order can be only one. Greenberg took into account only sentences with nominal subject and nominal object. As a rule the most frequent orders are SVO, SOV and VSO. The other three orders VOS, OSV, OVS are very rare and hardly reach the dominant status.
\end{abstract}

Spanish is traditionally considered SVO-language. Nevertheless there are contemporary linguistic investigations that give new information according to which the Spanish language is not only the type SVO but also the type VSO.

As for the old Spanish language there are different opinions: some linguists consider that the type VSO is an intermediate one between the Latin order SOV and modern Spanish order SVO, others refer the old Spanish language to the type SVO. Thus, the aim of the report is to analyze the types of simple narrative sentences in the language of formal letters written in old Spanish of the XIII century.

Based on the theory of $\mathrm{J}$. Greenberg the author examines models of simple sentences with so called full syntactic frame, i.e. models where subject and object are expressed by separate word. In models SVO, SOV, VSO, VOS, OSV, OVS the author distinguishes pronominal, nominal and pronominal-nominal ways of the subject expression, as well as the nominative object and pronominal object-clitic. The examples from formal letters dated by the XIII century show that the old Spanish language refers to the type SVO.

Keywords: Spanish, Old Spanish, Latin, business letter, simple sentence, word order, subject, predicate, object, SVO, SOV, VSO, VOS, OSV, OVS-models. 


\section{INTRODUCTION}

The term "basic order" is used by linguists in various meanings. Thus M. Dryer insists that the term "basic word order" can be applied to the order of any pair of elements, for example, to the adjective and the noun or to the verb and the negation (Dryer, 1997, p. 95). However, most often this term refers exclusively to the order of the main elements of the sentence: the subject $(\mathrm{S})$, the object $(\mathrm{O})$ and the verb-predicate $(\mathrm{V})$ (see: Greenberg, 1963; Tomlin, 1986). The combination of the subject and the predicate is already a sentence that represents a basic (minimum) subject-predicate center. The second argument of the predicate - object - is also very important in the expression of the subject-object relations in the structure of a simple sentence because in many cases a combination of the subject and the predicate is not enough.

L. Whaley associates the basic order with frequency, unmarkedness and neutrality (Whaley, 1997, pp. 100104). M. Dryer believes that the most reliable criterion is frequency; so he argues that the order can be considered as the basic if it exceeds all other possible orders, at least in the proportion 2:1 (Dryer, 1997, pp. 71, 74).

Serious attempts to study the word order as an element of surface syntactic structure were taken in the 60-s of the XX century. The pioneer in this field was the American linguist George Greenberg. Greenberg developed a classification that takes into consideration the order of the basic elements in a narrative sentence, provided that the subject and the object are expressed in nominal way. Logically six possible configurations or orders are identified: SVO, SOV, VSO, VOS, OSV, and OVS. Most languages allow different orders of the elements, but the dominant (base) can be only one.

According to Greenberg's theory only three of the above orders can be dominant: SVO, SOV or VSO. The other three orders (VOS, OSV, OVS) do not reach the dominant status or they are very rare. The common feature of the last three configurations is the precedence of the object to the subject (Greenberg, 1963, p. 4).

In many cases the order of the secondary elements depends on the order of the basic/main elements of the sentence (subject, predicate, object): if a language has SOV basic word order, it will probably have postpositions (but Persian, for instance, is SOV with prepositions) (Comrie, 1963, p. 19).

Despite of the fact that some Greenberg's theses have been criticized, many next investigations were written in the light of this theory and under its strong influence. This paper is not an exception. However, in contrast to the Greenberg's work, identifying the typology of the simple narrative sentence in the Old Spanish language by the example of formal letters, we took into account not only the examples with nominative subject and object, but also pronominal subject and object. We are based on the principal that the most concretized subjects are primarily personal pronouns. The endings of the verb in Spanish are also the ways of expression of grammatical subject. Nouns play the role of the grammatical subject only in the position of personal pronouns. Therefore, in case of the subject, pronominal form should be primary to nominal form. In case of the object - vice versa, because the grammatical object is the name of an object or a person to which the action is directed. That is why concerning to the object, pronominal form should be considered as the secondary one.

\section{THE SINTACTIC TYPE OF THE SPANISH LANGUAGE}

\subsection{Modern Spanish}

On the one hand, Spanish is characterized by a relative freedom of the word order because of the alternative ways that indicate the syntactic relations between the components of the sentence. On the other hand, Spanish has traditionally been considered as SVO language (sentences with this order are unmarked / neutral).

Nevertheless the recent studies represent new data. Thus, O. Fernandez Soriano gives the status of the alternative orders to VSO and VOS. The sentences $a, b$, and $c$ are considered as equally possible, in spite of their different interpretation:
a) Juan ha comprado el periódico. - "Juan has bought a newspaper." (SVO)
b) Ha comprado Juan el periódico. - "Has bought Juan a newspaper." (VSO)
c) Ha comprado el periódico Juan. - "Has bought a newspaper Juan." (VOS)

M.L. Zubizarreta considers that the basic orders in Spanish are SVO and VSO (Zubizarreta, 1999, p. 4217; op. cit. by Bernal, 2007, p. 3). A. Grouse and A. R. Bock-Bennema postulate VSO order as the basic one and the configuration SVO as the derivative of the VSO order. 
S. Gili y Gaya admits such orders in modern Spanish as SVO, VSO, VOS, OVS. The orders SOV*, OSV* are not used in colloquial speech and are very rare in literary prose. For example (Gili y Gaya, 1975, p. 83):

SVO: Mi padre compró una casa. - «My father bought a house».

SOV: *Mi padre una casa compró. - «My father a house bought».

VSO: Compró mi padre una casa. - «Bought my father a house».

VOS: Compró una casa mi padre. - «Bought a house my father».

OVS: Una casa compró mi padre. - «A house bought my father».

OSV: *Una casa mi padre compró. - «A house my father bought».

$\mathrm{H}$. Bernal, however, notes that the order OSV may be correct in Spanish, provided the prosodic boundary between the direct complement and the subject and the additional pronoun-clitic: A Maria, Juan la besó "Maria Juan (her) kissed." A sentence with the order SOV can also be acceptable if the prosodic boundary between the subject and the direct object is designated: Juan | a Maria besó - "Juan | Maria kissed" (Bernal, 2007, p. 3).

\subsection{Old Spanish}

In the works devoted to the linguistic change of the Latin language into the Romance (dominant local/national dialect of the Iberian Peninsula in the early Middle Ages; there were three Romance dialects in that period: Castilian, Aragon and Leon), the order of the constituents OV/VO is one of the main elements of the theory. The first order is main in the typology of the Latin language, the second - in the typology of the Romance (see: Tomlin, 1986; Siewierska, 1988; Dryer, 1997; Arnaiz, 1998, etc.). However, many authors (Adams, 1977; Pinkster, 1991, etc.) specify that in spite of the fact that classical Latin is the OV-language, it does not mean that the OV order was the only grammatical word order in Latin. VO order can also be found in the written Latin texts of different types.

$\mathrm{H}$. Pinkster gives the following data about the variations of the basic constituents $(\mathrm{S}, \mathrm{V}$ and $\mathrm{O})$ in the famous speeches in Latin (in absolute values, excepting Petronius's speeches - \%):

Table 1. Basic word orders in famous speeches in Latin (Pinkster, 1991, p. 72)

\begin{tabular}{|l|c|c|c|c|c|c|}
\hline & SOV & SVO & OSV & OVS & VSO & VOS \\
\hline Cicero (Att.) & 17 & - & 2 & - & 1 & - \\
\hline Caesar (Gall + Civ) & 360 & 22 & 120 & 33 & 6 & 27 \\
\hline Vitruvius & 7 & 4 & 2 & 1 & - & - \\
\hline Celsus & 51 & 4 & 6 & 15 & - & 7 \\
\hline Petronius (in \%) & 46 & 19 & 15 & 6 & 6 & 6 \\
\hline Claudius Terentianus & 3 & 10 & 1 & 1 & 1 & 4 \\
\hline Peregrinatio - Part 1 & 22 & 35 & 6 & 4 & 15 & 22 \\
\hline Peregrinatio - Part 2 & 10 & 16 & 3 & 1 & 14 & 29 \\
\hline Vulgata (100 sentences) & 15 & 8 & - & - & - & - \\
\hline
\end{tabular}

As for the early Romance G. Bossong considers it as the VSO language. M. Suárez Fernández objects to this opinion. She explains that the initial position of the verb is unlikely, because the predication should be characterized by two nominative components (agent and patience / object) (Suárez Fernández, 2007, p. 225). The author says that the logical order in the first texts in Romance and in the following ones is SVO order.

One of the samples of the early Romance are "San Millan glosses" (glosses from the San Millan Monastery), San Millan glosses were studied by R. Blake. The author considers that they are samples of the Ancient Spanish language with Latinized orthography dated by the IX-XI centuries. Blake's investigation shows the following results (Blake, 1992, p. 294):

Table 2. Basic word orders in "San Millan glosses" (Blake, 1992, p. 294)

\begin{tabular}{|l|c|c|c|}
\hline \multicolumn{1}{|c|}{ Word order } & IX century & X century & XI century \\
\hline $\mathrm{SOV}(\%)$ & 12 & 19 & 13 \\
\hline $\mathrm{O}_{1} \mathrm{~V}(\mathrm{~S}) \mathrm{O}_{2}(\%)$ & 6 & 1 & 11 \\
\hline $\mathrm{SVO}(\%)$ & 38 & 38 & 45 \\
\hline $\mathrm{V}(\mathrm{S}) \mathrm{O}(\%)$ & 44 & 37 & 38 \\
\hline $\mathrm{VO}(\%$ всего $)$ & 82 & 75 & 83 \\
\hline
\end{tabular}


G. Bossong finds the evidence of the VSO order in these glosses. He considers it as an intermediate step between the Latin SOV order and the Romance SVO order (Bossong, 1998, pp. 1014-1015). According to the author's opinion the evolution from Latin to the Romance has gone through three orders: the classical Latin SOV order - Late Latin / early Romance VSO order - modern Spanish SVO order.

It seems that this division into periods is not quite satisfactory, as it excludes a large linguistic layer that is located between early Romance and modern Spanish. It is neither Romance nor modern Spanish. It is common subnational base of the Kingdom Castile and Leon that allow reading and understanding texts for non-native speakers. We call this subnational linguistic base (that is found since XIII century) the Old Spanish Language.

In the next part of the paper we present the results of our investigation that examines the models of simple sentences in the texts of formal letters (most of them are royal) dated by the XIII century.

\section{MODELS OF SIMPLE SENTENCES IN THE OLD SPANISH FORMAL LETTERS (XIII CENTURY)}

In Old Spanish formal letters there are following configurations of simple sentences:

1) The order SVO

According to some linguists the models with a linear SVO-order "reflect" the natural order from the known things to the unknown things.

There are models with nominative object (a) and pronominal object-clitic (b).

a) SVO-orders with nominative object:

- ... a que yo pus nombre Torquemada (Corpus, $n^{0} 1208$ ). - The letter of the King of Castile Alfonso $X$ dated 25 November, 1253. - "to which [village] I gave the name of Torquemada."

- E el por nuestro mandado llamo omes buenos de las villas sobredichas ... (Serrano, 1906, p. 116). The letter of the King of Castile Alfonso X dated 13 June, 1270. - "And he, by our order, called noble men from the above mentioned towns."

- el abat e los monges de Oña ... mostráronme privilegio plomado de mio avuelo el rey don Alfonso (Corpus, $n^{\circ}$ 0504). - The letter of the King of Castile Ferdinand III dated by 1239. - "the abbot of the monastery and nuns of the monastery of Onya ... showed me the lead privilege (with lead seal) of my grandfather, the King Don Alfonso."

- Et yo, sobredicho rey don FERNANDO ... con mi mano propria robro esta carta ... (Ostos Salcedo, 1996, p. 247). - The Royal letter dated by 1252. - "And I, the above mentioned king, Don Fernando ... personally assure that letter."

b) SVO-orders with pronominal object-clitic:

- Et yo, sobredicho rey don FERNANDO ... confirmola (Ostos Salcedo, 1996, p. 247). - The Royal letter dated by 1252. - "And I, the above mentioned king, Don Fernando ..., confirm it [the letter]."

\section{2) The order SOV}

Traces of the Latin norm (S)OV in Old Spanish formal letters are found primarily in the initial and final protocols. Compare:

- ... quando yo las conquisiere ... (Ostos Salcedo, 1996, p. 247). - The letter dated by 1252. - "when I them [the villages] conquer."

- Don Aboabdille Abennaçar, rey de Granada, vasallo del rey, la confirma (Corpus, $n^{0} 1208$ ). - The letter dated by 1253. - "Don Aboabdil Abenasar, the King of Granada, the vassal of the king, confirms it (literally: Don Aboabdil it confirms)."

- Yo, Johán Pérez de Cibdat, la escriuí por mandado de Millán Pérez de Aellón, en el anno ... (Corpus, $n^{0}$ 252). - The letter dated by 1252. - "I, Juan Perez de Sibdat, wrote it (literally: it wrote) by the order of Millan Perez de Aellon, in the year (such and such) ...".

- * ...yo fernan gonçaluiz esta carta || que mande fazer conmyas manos \|| la Rouro \& signo fago (Corpus, $n^{\circ}$ 0472). - The clerical letter dated by 1255. - "And I, Fernand Gonsalves, this letter, which I ordered to make, assure it personally (literally: it assure) and put a sign." 
The last example $\left({ }^{*}\right)$ shows an extremely rare case of pronominal reprise - duplication of a nominative object (esta carta - "this letter") that is located before a verb (rouro - "assure") by pronoun-clitic (la - "it" [letter]). As usual the pronominal reprise was not used in Old Spanish formal letters even in the later period.

3) The order VSO

- E el cambio es atal: que dó yo a vós el castiello e la villa de Veas ... (Corpus, $\left.n^{\circ} 1200\right)$. - Letter dated by 1239. - "And the exchange is as follows: give I to you the castle and the village of Veas."

\section{4) The order OSV}

The only example with this configuration was found in a document dated by 1239. It is the letter of the King of Castile Fernando III. The paper (the so called privilege) delimitates and determines the borders between Madrid and Segovia, and between the villages of these two towns. Compare:

- "É mando e defiendo firmemientre que ninguno no sea osado de mudar nin de camiar ninguno destos sobredichos mojones de || commo los yo pus" (Cavanilles, 1999, p. 58). - "... And I order and strictly insist that no one dared to move or change any of the above pillars from how I have put them (literally: them I put)."

In this sentence the object expressed by the pronoun-clitic (Ios) is located in a distant (!) position from the verb. Such a phenomenon, that is called interpolation, is totally unacceptable in modern Spanish.

\section{5) The order OVS}

The models of simple sentences with this structure (OVS) also refer to the period of the Middle Ages.

- E este fito fiz yo (Corpus, $\mathrm{n}^{0}$ 1209). - The letter dated by 1241 . - "This pillar did I." - ... con todo aquello que pertenece al aldea de los términos adentro assí como la amojonaron don Remondo, obispo de Segovia, e vós don Gonçalvo García de Torquemada e Roy López de Mendoça por mio mandado (Corpus, $\mathrm{n}^{\circ}$ 1208). - The letter dated by 1253 . - "... with all things that belong to the village within the boundaries as Don Rémond, Bishop of Segovia, and you, don Gonsalvo Garcia de Torquemada, and Roy Lopez de Mendoza delimitated it, by my order (literally: it delimitated Don Remondo and others)."

It should be remembered that in modern Spanish, the preposition of an object to a subject causes pronominal duplication by pronoun-clitic. As for old Spanish in formal letters there are few examples with double object. Compare:

- (S) Yo Pedro Cosme e yo María Cosme (O) esta carta ... con nuestras manos ( $\mathrm{O}_{\text {pronoun }}$ la $(\mathrm{V})$ rovramos et signa facimus (Corpus, $\mathrm{n}^{\circ}$ 0473]. - The letter dated by 1226. - "I, Pedro Cosme, and I, Maria Cosme, assure this letter with our own hands and put the seal on it (literally: "this letter it (we) assure).

Compare with the previous sentence: este fito fiz yo↔ este fito (?) lo fiz yo.

6) The order VOS

- Escriuióla Sancho Fernández, escriuano del rey (Ostos Salcedo, 1996, p. 247). - The letter dated by 1252. - "Wrote it [the letter] Sancho Fernandez, the notary of the king."

According to our study (43 simple sentences in 11 letters) in the language of formal letters written in Old Spanish there can be following types of simple sentences: SVO - 49\%; SOV - 21\%; OVS - 16\%; VSO $7 \%$; VOS - $5 \%$; OSV - $2 \%$.

Thus, like most languages, the language of formal letters written in Old Spanish allows different models of simple sentences with the basic elements $\mathrm{S}$ - subject, $\mathrm{O}$ - object and V - verb-predicate, but the only one should be considered as dominant - SVO. Such a structure is the most frequent and neutral in this type of texts.

\section{REFERENCE LIST}

Adams J. N. (1977). The Vulgar Latin of the Letters of Claudius Terentianus (P. Mich. VIII, 467-72). Manchester: Manchester University Press.

Arnaiz A. R. (1998). An overview of the main word order characteristics of Romance // Constituent Order in the Languages of Europe. Berlin: Mouton de Gruyter. 
Bernal M. J. (2007). El orden de palabras de la oración simple en español y en griego // Revista electrónica de didáctica / español lengua extranjera, № 9. URL: http://www.mecd.gob.es/dctm/redele/MaterialRedEle/Revista/2007_09/2007_redELE_9_01Bernal.pdf?documentld=0901e72b80df390b

Blake R. (1992). Aspectos sintácticos del español antiguo: Cartulario de San Millán de la Cogolla // En Ariza, M. et al. (eds.): Actas del II Congreso internacional de Historia de la Lengua Española, Madrid: Pabellón de España, Vol. I.

Bossong G. (1998). La typologie des langues romanes // En Holtus, G., M. Metzeltin \& C. Schmitt (eds.): Lexikon der Romanistischen Linguistik, vol. VII.

Cavanilles A. (1999). Memoria sobre el Fuero de Madrid, del año de 1202 // Memorias de la Real Academia de Historia. Alicante: Biblioteca Virtual Miguel de Cervantes.

Comrie B. (1981) Language Universals and Linguistic Typology. Syntax and Morphology. Oxford.

Corpus de documentos españoles anteriores a 1800 [CODEA+]. URL: http://corpuscodea.es/\#presentationhidden-documentos

Dryer M. (1997). On the Six-Way Word Order Typology // Studies in language 21:1. URL: http://wings.buffalo.edu/linguistics/people/faculty/dryer/dryer/Dryer6Way1997.pdf

Gili y Gaya S. (1975). Curso Superior de Sintaxis Española. La Habana: Editorial Pueblo y Educación.

Greenberg J. (1963). Some universals of grammar with particular reference to the order of meaningful elements // In: Joseph H. Greenberg (ed.). Universals of Language. London: MIT Press. URL: http://pkdas.in/JNU/typo/lu.pdf

Groos A., Bok-Bennema R. (1986). The structure of the sentence in Spanish // Generative Studies in Spanish Syntax. Dordrecht (Holanda) y Riverton (EE.UU.): Foris Publications.

Ostos Salcedo P., Sanz Fuentes M. J. (1996). Corona de Castilla. Documentación real. Tipología (12501400). // Diplomatique Royale du Moyen Âge, Oporto. URL: http://ler.letras.up.pt/uploads/ficheiros/3829.pdf

Pinkster H. (1991). Evidence for SVO in Latin? // Latin and the Romance Languages in the Early Middle Ages. London/New York: Routledge.

Serrano L. (1906). Fuentes para la historia de Castilla. Valladolid.

Siewierska A. (1988). Word order rules. London/New York/Sydney: Croom Helm. URL: https://www.academia.edu/7179671/Word_Order_Rules

Suárez Fernández M. (2007). El orden de constituyentes en el romance temprano. Las Glosas Emilianenses // Moenia., vol. 13. URL: https://dspace.usc.es/bitstream/10347/6071/1/09-

Su\%C3\%A1rez\%20Fern\%C3\%A1ndez.pdf

Tomlin R. S. (1986). Basic Word Order: Functional Principles. London: Croom Helm.

Whaley L. (1997). Introduction to Typology. London: Sage Publications.

Zubizarreta M. L. (1999). Las funciones informativas: tema y foco // Gramática descriptiva de la lengua Española. Madrid: Real Academia Española y Espasa Calpe, Vol. 3. 